International Journal of Business Management and Economic Review

Vol. 4, No. 04; 2021

ISSN: 2581-4664

\title{
THE EFFECT OF LEADERSHIP STYLE AND WORK ENVIRONMENT ON MOTIVATION AND ITS IMPLICATION ON EMPLOYEE PERFORMANCE: STUDY ONMA'HAD DAARUT TAHFIZH AL-IKHLAS
}

\author{
*Mochammad Reza, Nurdasila and Hafasnuddin \\ Management Department, Universitas Syiah Kuala, Indonesia \\ http://doi.org/10.35409/IJBMER.2021.3285
}

\begin{abstract}
This study aims to examine the model of Leadership Style And Work Environment Effect On Motivation And Its Implication On Employee Performance. This research was conducted at Ma'had Daarut Tahfizh Al-Ikhlas, in Aceh Besar District, Indonesia. The sample determined was equal to the population, that was as many as 122 respondents. To test the respondents' perceptions, the authors used the Likert scale. Then, structural equation modeling (SEM) was used as a set of statistical techniques to test the causality effects. The result proves the causality hypothesis in this study, namely :Leadership style significantly affects work motivation of employees of Ma'had Daarut Tahfizh Al-Ikhlas, Work environment significantly affects work motivation of employees of Ma'had Daarut Tahfizh Al-Ikhlas, Leadership style significantly affects performance of employees of Ma'had Daarut Tahfizh Al-Ikhlas, Work environment significantly affects performance of employees of Ma'had Daarut Tahfizh Al-Ikhlas, and Work motivation significantly affects performance of employees of Ma'had Daarut Tahfizh Al-Ikhlas. These findings prove that the employee performance improvement model is formed from a suitable leadership style and a good work environment in supporting employees at work, so that it will have an impact on employee performance directly or either through increased work motivation. These findings provide a useful premise for the academic realm, especially for the basis of further research. Future researchers are expected to be able to develop this tested model of employee performance by adding new variables such as organizational culture and organizational citizenship behavior.
\end{abstract}

Keyword: Leadership Style, Work Environment, Motivation, Employee Performance.

\section{INTRODUCTION}

Employee performance greatly affects the success of an organization's goals, seeing the importance of employees in an organization. This is following the opinion of (Koopmans, Bernaards, Hildebrandt, \& Buuren, 2014) that performance is defined as behavior or action that is relevant to organizational goals. It can be said that employees are a valuable organizational asset, hence the need for support and development to make employees' abilities good.

(Ali \& Ahmad, 2009) argued that performance is carrying out an activity and perfecting it according to their responsibilities with results as expected. One of the efforts to improve employee performance can be done by applying policies and directives from a reliable and 


\section{International Journal of Business Management and Economic Review}

Vol. 4, No. 04; 2021

ISSN: 2581-4664

highly motivated and focused leader. The policies of each organization or agency in providing rules for achieving different goals.

Ma'hadDaarutTahfizh Al-Ikhlas is a private educational institution under the auspices of the foundation and the Ministry of Religion of Indonesia, located in Aceh Besar District. Ma'hadDaarutTahfizh Al-Ikhlas has three formal education, namely Madrasah IbtidaiyahTerpadu (MIT), Madrasah TsanawiyahTerpadu (MTsT) and Madrasah AliyahTerpadu (MAT). This educational institution is engaged specifically in the field of tahfizh Al-Qur'an or memorizing the Al-Qur'an, then added with other general education such as science, social science, and so on.

Then employee motivation becomes very important in an organization to increase passion and morale, employees will have motivation according to their abilities if an institution can meet the needs of employees. Motivation is all the power that exists in someone who empowers, directs, and maintains the behavior in question. In our daily lives, motivation is defined as the whole process of giving encouragement or stimulation to employees, so that they are willing to work willingly without feeling forced (Anggrainy, Darsono, \& Putra, 2018).

To explain some of the motivation theories cited by (Andjarwati, 2015), namely Abraham Maslow's theory of needs, that motivation is a work impulse that arises in a person to meet their needs. There are five levels of human need; (1) physiological needs, (2) security needs, (3) social needs, (4) appreciation needs, and (5) self-actualization needs.

Another factor that also influences motivation is the leadership style that the superior has towards his subordinates. Leadership style or leadership behavior, namely a leader in carrying out various leadership functions and is influenced by various factors, including education, experience, personality, and situation (Vincent-Höper, Muser, \& Janneck, 2012).Leadership can also be interpreted as the ability to direct followers to cooperate with trust and to be able to do a job well. A leader always has the authority to govern subordinates with their respective leadership styles and subordinates will receive orders from their leaders with different views (Soekarso \& Putong, 2015).

The leadership style that exists in a leader in an institution has differences where the application of this leadership style can influence employees. Leadership style is a behavioral norm that is used by a person when that person tries to influence the behavior of others (Byars \& Rue, 2006).Leadership is not sufficient to increase employee motivation if it is not supported by work environment factors. A satisfactory work environment can improve performance (AlQura'an, 2015).

Humans will be able to carry out their activities well so that optimal results can be achieved if they are supported by environmental conditions accompanied by adequate work facilities to support the work of employees. In addition, an adequate work environment and in good condition can also improve employee performance, this can be seen with facilities and facilities that are supported by good technology that will be able to facilitate and facilitate each employee's work so that work can be carried out properly and on time. achieve work effectiveness and efficiency (Rufino, 2012).

Therefore, the leadership style and work environment are the factors that influence the success of an organization, so a leader will take various steps to achieve more competent employee performance in carrying out work activities. One of the ongoing efforts is, trying to get all employees to be motivated to work at the organization. 
International Journal of Business Management and Economic Review

Vol. 4, No. 04; 2021

ISSN: 2581-4664

\section{LITERATURE REVIEW}

Employee Performance

(Werther \& Davis, 1996) stated performance is the level of achievement of a person or employee in an organization or company that can increase productivity. While (Van Hoek, 1999) revealed that the performance is the success that an individual can achieve in doing his job, where the measure of success achieved by an individual cannot be equated with other individuals. (Strauss \& Sayles, 2012) said that performance is a universal concept regarding the operational effectiveness of an administration, part of the organization, and its employees based on predetermined standards and criteria, because the organization is basically run by humans, then performance is actually human behavior in playing a role they do in an organization to meet the standards of behavior that have been set in order to produce the desired action and results.

\section{Work Motivation}

Work Motivation is a driving force that results in an employee willing and willing to mobilize the ability to form the skills and skills of the personnel and the time to carry out various activities that are their responsibility and fulfill their obligations in order to achieve goals. According to (Arifin, 2013), it was explained that work motivation has a meaning as a mental attitude and a human psychological state that provides energy, drives / encourages activities and leads/channels behavior towards achieving needs that provide satisfaction or reduce imbalances.According to (Robbins \& Judge, 2017), motivation is the willingness to make highlevel efforts to achieve organizational goals that are conditioned by the ability of the business to satisfy the needs of a number of individuals.Meanwhile, according to (Wexley \& Yuki, 2005) motivation is a psychological factor that shows an individual's interest in work, a sense of satisfaction, and is responsible for the activity or work that is carried out.

\section{Leadership Style}

The leadership style according to (Luthans, 2013) is a pattern of actions of the leader as a whole as perceived by employees. This indicates that the leadership style can be a role model for employees in running the organization to achieve goals. The relationship between a leader and being led is a leadership process because the leader needs followers and followers need the leader. Although leaders and followers are related to each other, leaders should often take the initiative to establish relationships, communicate and maintain relationships so that organizational goals as formulated in the organization's vision, mission, plans, and strategies can be achieved.Every organization has different leadership because each leader has his style in influencing his followers/subordinates. Leadership style shows a leader's belief in his subordinates, how a leader influences his subordinates/followers is shown in the behaviors, strategies, traits, attitudes, etc. that are often applied by a leader. Each leader may have a different leadership style from one another, but that does not mean that a leadership style is considered better or better because the situation in which they are in is very decisive.

In today's democratic society leadership plays an important role because with good leadership the organization can run according to the expected goals. (Mathis \& Jackson, 2011), stated that "leadership is seen as an individual skill (skill) so that training is needed". The problem of leadership can be interpreted in various ways, this depends on the point of view and the research context of the experts who discuss it. Some of the limitations of the notion of 


\section{International Journal of Business Management and Economic Review}

Vol. 4, No. 04; 2021

ISSN: 2581-4664

leadership described below are related to the research context and the variables that are the research target.

\section{Work Environment}

A conducive work environment provides a sense of security and allows employees to work optimally. According to (J. Peters \& H. Waterman, 1982), the work environment is the entire tooling tool and material faced, the surrounding environment where a person works, his work methods, and work arrangements both as an individual and as a group. Another opinion is also expressed by him that the condition of the work environment is said to be good or appropriate if humans can carry out activities in an optimal, healthy, safe, and comfortable manner. The consequence of the suitability of the work environment can be seen in the long term, furthermore, unfavorable work environments can demand more labor and time and do not support the attainment of an efficient work system design. So it explains that the work environment is everything that is around the workers/employees that can affect the the performance of the employees, including the work facilities.

\section{Previous Research Review}

Research conducted by (Hidayat, Lubis, \& Majid, 2019) provided participatory leadership style has an influence on improving employee performance. Then the research conducted by (Bahagia, 2017) stated that the work motivation of employees has an influence in improving employee performance. Meanwhile, research conducted by (Oktavina, Nurdasila, \& Kesuma, 2018), where the results of the study proved that the work motivation of employees has an influence on improving employee performance. Then the research by (Yunus, Iis, Adam, \& Sofyan, 2020), where the results of the study show that the work motivation of employees has a direct effect on improving employee performance with an estimated coefficient value of 0.68 , which means that motivation has a positive effect.

\section{Hypothesis}

Furthermore, the authors formulated the research hypothesis for examining the model of employee performance in the Ma'had Daarut Tahfizh Al-Ikhlas, namely :

H1 : Leadership style significantly affects work motivation of employees of Ma'had Daarut Tahfizh Al-Ikhlas.

H2 : Work environment significantly affects work motivation of employees of Ma'had Daarut Tahfizh Al-Ikhlas.

H3 : Leadership style significantly affects performance of employees of Ma'had Daarut Tahfizh Al-Ikhlas.

H4 : Work environment significantly affects performance of employees of Ma'had Daarut Tahfizh Al-Ikhlas.

H5 : Work motivation significantly affects performance of employees of Ma'had Daarut Tahfizh Al-Ikhlas.

\section{METHOD}

This study was carried out at Ma'had Daarut Tahfizh Al-Ikhlas in Aceh Besar District, Indonesia. The sample determined was equal to the population, that was as many 
International Journal of Business Management and Economic Review

Vol. 4, No. 04; 2021

ISSN: 2581-4664

as 122 respondents.To test the respondents' perceptions, the authors used the Likert scale.Questionnaires were distributed to collect the perception data. Then, structural equation modeling (SEM) was used as a set of statistical techniques to testthe causality effects(Ferdinand, 2014).

\section{RESULT AND DISCUSSION}

Result

The next analysis is a full model Structural Equation Model (SEM) analysis, after analyzing the uni-dimensionality level of the latent variable forming indicators tested by confirmatory factor analysis. Analyzing was carried out by performing a suitability test and statistical test. The results are shown in the following Figure.

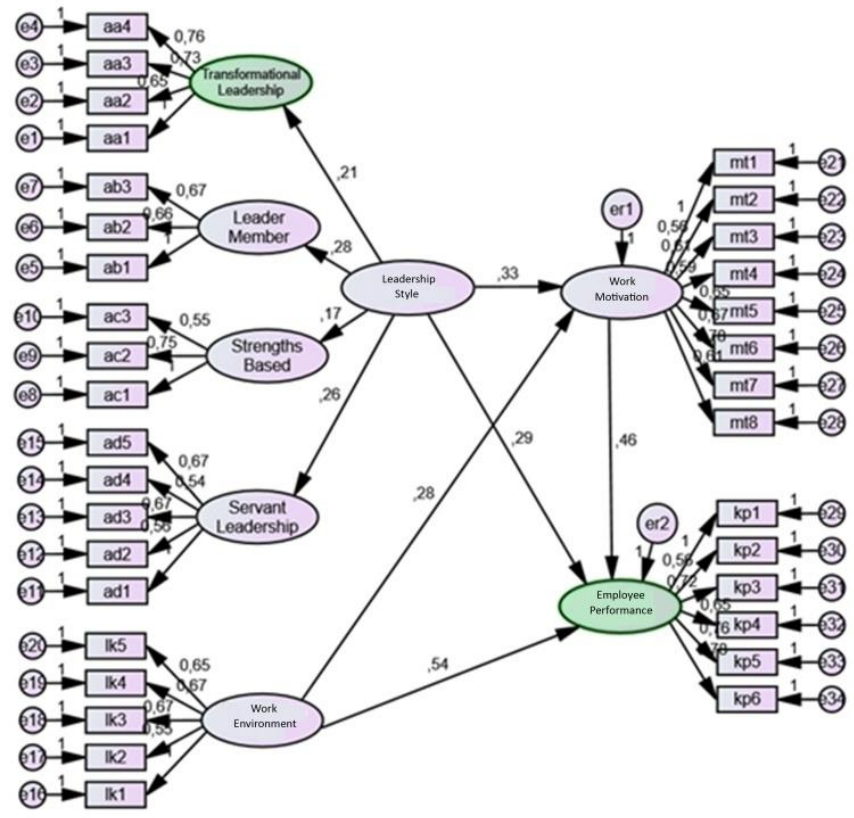

Figure 1. Structural Model Test Result (SEM)

Hypothesis 1

Testing the Leadership Style Effect on Work Motivation provides the critical ratio (CR) estimation parameter value of 6.222 and with a probability (p-value) of 0.000 . Thus the $C R$ value is higher than the t-table value of 1.97 and the p-value is lower than 0.05 . Thus the alternative hypothesis (Ha)for Hypothesis 1 is accepted and the null hypothesis (Ho) is rejected because the significance value is 0.000 .

\section{Hypothesis 2}

Testing the Work Environment Effect on Work Motivation provides the CR of 3.474 which is higher than the t-table of 1.97 and the p-value is lower than 0.05 . Thus the Ha for Hypothesis 2 is accepted and the Ho is rejected because the significance value is 0.000 . 


\section{International Journal of Business Management and Economic Review}

Vol. 4, No. 04; 2021

ISSN: 2581-4664

Hypothesis 3

Testing the Leadership Style Effect on Employee Performance obtained the CR of 8.765 which is higher than the t-table value of 1.97 and the p-value is lower than 0.05 . Thus the Ha for Hypothesis 3 is accepted and the Ho is rejected because the significance value is 0.000 .

\section{Hypothesis 4}

Testing the Work Environment Effect on Employee Performance provides the CR estimation parameter value of 7.297 which is higher than the t-table value of 1.97 and the p-value is lower than 0.05 . Thus the Ha for Hypothesis 4 is accepted and the Ho is rejected because the significance value is 0.000 .

\section{Hypothesis 5}

Testing The Work Motivation Effect on Employee Performance provides the CR estimation parameter value of 8.214 which is higher than the t-table value of 1.97 and the p-value is lower than 0.05 . Thus the Ha for Hypothesis 5is accepted and the Ho is rejected because the significance value is 0.000 .

\section{Discussion}

The results of this study imply that leadership style has a positive impact on employee motivation at Ma'had Daarut Tahfizh Al-Ikhlas. Increasing employee work motivation based on leadership style variables can be seen from the leadership always motivating subordinates in carrying out their duties, the leadership always sets each employee with high targets in the determined work achievement. Leaders always appreciate differences of opinion in an organizational environment. This result is consistent with research conducted by (Ariyanto \& Mariani, 2012), that leadership style will have an impact on increasing work motivation and improving employee performance at Ma'had Daarut Tahfizh Al-Ikhlas.

The results of the study indicate that the leadership style applied by the leadership at Ma'had Daarut Tahfizh Al-Ikhlas has a positive effect on employee motivation, which means that the leadership style in leading their subordinates is able to encourage employees to work better, this can be seen from the magnitude of the leadership style on affecting the motivationof workof Ma'had Daarut Tahfizh Al-Ikhlas employee.

The results of this study also imply that the work environment at Ma'had Daarut Tahfizh Al-Ikhlas has an influence on increasing employee motivation, especially the presence of sufficient light in every workspace, adequate air circulation in each workspace, employee agencies. free from unpleasant odors in every workspace so as to provide motivation and job satisfaction and have an impact on improving employee performance.

Then the effect of work motivation on the performance of employees of Ma'had Daarut Tahfizh Al-Ikhlas has a very significant effect so that the work motivation of employees will have an impact on improving employee performance to be even better, this is reinforced by the results of research that conducted by (Tjahjono, 2006) which stated that the work motivation of employees can have a significant effect on improving employee performance.

\section{CONCLUSION}

The result proves the causality hypothesis in this study, namely: Leadership style significantly 


\section{International Journal of Business Management and Economic Review}

Vol. 4, No. 04; 2021

ISSN: 2581-4664

affects work motivation of employees of Ma'had Daarut Tahfizh Al-Ikhlas, Work environmentsignificantly affects work motivation of employees of Ma'hadDaarutTahfizh AlIkhlas, Leadership style significantly affects performance of employees of Ma'hadDaarutTahfizh Al-Ikhlas, Work environment significantly affects performance of employees of Ma'hadDaarutTahfizh Al-Ikhlas, and Work motivation significantly affects performance of employees of Ma'hadDaarutTahfizh Al-Ikhlas. These findings prove that the employee performance improvement model is formed from a suitable leadership style and a good work environment in supporting employees at work, so that it will have an impact on employee performance directly or either through increased work motivation. These findings provide a useful premise for the academic realm, especially for the basis of further research. Future researchers are expected to be able to develop this tested model of employee performance by adding new variables such as organizational culture and organizational citizenship behavior.

Several recommendations have been mapped out from the results of this study, which are useful for improving employee's performance of Ma'hadDaarutTahfizh Al-Ikhlas in the future. The first one is, In order to increase the work motivation of Ma'had Daarut Tahfizh AlIkhlas employees based on a leadership style perspective, what needs to be improved is the application of a transformational leadership style because it has the lowest average value so that it will have an influence on work motivation and employee performance. Then the second is, To increase the work motivation of Ma'had Daarut Tahfizh Al-Ikhlas employees based on the perspective of the work environment, what needs to be paid attention is to create a comfortable, safe work environment in the environment so that employees can carry out the teaching and learning process with a feeling of pleasure and feeling safe. Furthermore, the third recommendation is, To improve the performance of Ma'had Daarut Tahfizh Al-Ikhlas employees based on the perspective of work motivation, what needs attention is that the leadership should have the ability to manage resources at Ma'had Daarut Tahfizh Al-Ikhlas so that the expected performance achievement will be realized. And, The fourth one is, In order to improve the performance of Ma'had Daarut Tahfizh Al-Ikhlas employees based on the perspective of job satisfaction, what needs to be paid attention is that the leadership style should be implemented by the leadership by prioritizing the participation of all employees, especially in solving any problems that arise in the organizational environment.

\section{REFERENCES}

Al-Qura'an, A. (2015). The Impact of Transformational Leadership on Organizational Change Management: Case Study at Jordan Ahli Bank. IOSR Journal of Business and Management (IOSR-JBM), 17(12), 1-7. https://doi.org/10.9790/487X-171210107

Ali, R., \& Ahmad, M. S. (2009). The Impact Of Reward And Recognition Programs On Employee's Motivation And Satisfaction A Co Relational Study. International Review of Business Research Papers, 5(4), 270-279.

Andjarwati, T. (2015). Motivasi dari Sudut Pandang Teori Hirarki Kebutuhan Maslow, Teori Dua Faktor Herzberg, Teori X Y Mc Gregor, dan Teori Motivasi Prestasi Mc Clelland. Jurnal Ilmu Ekonomi Dan Manajemen, 2(1), 45-54. https://doi.org/https://doi.org/10.30996/jmm17.v2i01.422

Anggrainy, I. F., Darsono, N., \& Putra, T. R. I. (2018). Pengaruh Fasilitas Kerja, Disiplin Kerja, dan Kompensasi Terhadap Motivasi Kerja serta Implikasinya Pada Prestasi Kerja Pegawai 
Negeri Sipil Badan Kepegawaian Pendidikan dan Pelatihan Provinsi Aceh. Jurnal Magister Manajemen, 2(1), 1-10.

Arifin, M. (2013). The Influence of Competence and External Motivation Factor toward Teachers Working Performance in Jayapura - Papua Indonesia. IOSR Journal of Business and Management, 7(5), 1-7.

Ariyanto, A., \& Mariani. (2012). Pengaruh Gaya Kepemimpinan dan Motivasi Kerja Terhadap Kinerja Pegawai Pada Dinas Bina Marga dan Cipta Karya Provinsi Aceh. Jurnal Ilmiah Manajemen Muhammadiyah Aceh, 2(2). https://doi.org/https://doi.org/10.37598/jimma.v2i2.343

Bahagia, S. (2017). Pengaruh Kompetensi, Reward, Dan Motivasi Pegawai Terhadap Kinerja Pegawai Serta Dampaknya Pada Pengembangan Karir Di Dinas Sosial Aceh. Syiah Kuala University.

Byars, L. L., \& Rue, L. W. (2006). Human Resource Management (8th, revised ed.). New York: MCGraw-Hill, Irwin.

Ferdinand, A. (2014). Metode Penelitian Manajemen (Edisi 5). Semarang: Universitas Diponegoro.

Hidayat, S., Lubis, A. R., \& Majid, M. S. A. (2019). Pengaruh Gaya Kepemimpinan, Kerjasama Tim Dan Kompensasi Terhadap Kinerja Karyawan Melalui Kepuasan Kerja Karyawan Pada PT. Dunia Barusa Banda Aceh. Jurnal Perspektif Ekonomi Darussalam, 5(1), 86-100. https://doi.org/https://doi.org/10.24815/jped.v5i1.14088

J. Peters, T., \& H. Waterman, R. (1982). In Search of Excellence: Lessons From America's BestRun Companies. https://doi.org/10.2307/2393015

Koopmans, L., Bernaards, C., Hildebrandt, V., \& Buuren, S. van. (2014). Improving the Individual Work Performance Questionnaire using Rasch Analysis. Journal of Applied Measurement, 15(2), 160-175. https://doi.org/10.1136/oemed-2013-101717.51

Luthans, F. (2013). Organizational Behavior An Evidence-Based Approach (8th ed.). New York: Mc Graw Hill.

Mathis, R. L., \& Jackson, J. H. (2011). Human Resource Management: Essential Perspectives (6th ed.). USA: Cengage Learning.

Oktavina, E., Nurdasila, \& Kesuma, T. M. (2018). Pengaruh Gaya Kepemimpinan, Motivasi Kerja Dan Komunikasi Terhadap Kepuasan Kerja Dan Dampaknya (Syiah Kuala University). Retrieved from etd.Unsyiah.ac.id

Robbins, S. P., \& Judge, T. A. (2017). Essential of Organisational Behaviour (14th ed.). New Jersey: Pearson.

Rufino, F. (2012). Pengaruh Kepemimpinan, Motivasi dan Lingkungan Kerja terhadap Kinerja Karyawan di Grand Mahattan Club. Universitas Esa Unggul, Jakarta.

Soekarso, \& Putong, I. (2015). Kepemimpinan: Kajian Teori dan Praktis. Jakarta: Buku\&Artikel Karya Iskandar Putong.

Strauss, G., \& Sayles, L. R. (2012). Pribadi-Masalah Manusia Manajemen. Jakarta: Erlangga.

Tjahjono, B. N. (2006). Pengaruh Motivasi Kerja dan Budaya Organisasi terhadap Kinerja Pegawai di Lingkungan Bina Marga Provinsi Jawa Tengah. Universitas Muhammadiyah Surakarta.

Van Hoek, R. I. (1999). The Horizontal Organization. Supply Chain Management: An International Journal. https://doi.org/10.1108/scm.1999.4.5.254.1 
International Journal of Business Management and Economic Review

Vol. 4, No. 04; 2021

ISSN: 2581-4664

Vincent-Höper, S., Muser, C., \& Janneck, M. (2012). Transformational leadership, work engagement, and occupational success. Career Development International, 17(7), 663-682. https://doi.org/10.1108/13620431211283805

Werther, W. B., \& Davis, K. (1996). Human Resources and Personnel Management (5th Editio). New York: McGraw-Hill.

Wexley, T., \& Yuki, A. (2005). Perilaku Organisasi \& Psikologi Personalia: Jilid I. Jakarta: PT Rineka Cipta.

Yunus, M., Iis, E. Y., Adam, M., \& Sofyan, H. (2020). Does Motivation Mediate the Effects of Employee Staff Empowerment, Talent, Working Environment, and Career Development on Staff Performance? Quality Management, 21(175), 91-96. 